الجمعية المصرية للقر اءة و المعرفة عضو الجمعية الدولية للمعرفة

\title{
An Overview on EFL Prospective Teacher's Instructional Communication Skills
}

\section{Maha Samir El- Bayaa}

Assistant Lecturer at Dept. of Curriculum and Instruction (TEFL), Faculty of Education, Port- Said University.

\section{Dr. Zeinab Ali EL-Naggar}

Professor of Curriculum and Methods of Teaching English, Faculty of Education, Ain- Shams University.

Dr. Walaa Mohamed EL-Henawy

Lecturer of Curriculum and Methods of Teaching English, Faculty of Education, Port- Said University. 


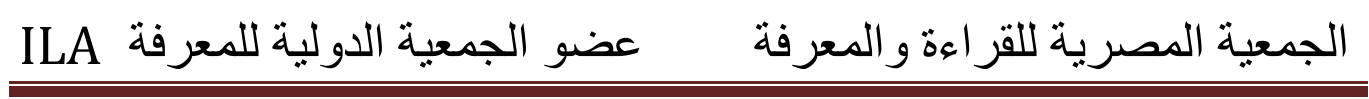




\section{Abstract}

Instructional communication is a unique area of study. It is rooted in research conducted among educational psychology, pedagogy, and communication studies. It is the process by which teachers and students stimulate meanings in the minds of each other using verbal and nonverbal messages that result in positive educational outcomes. EFL prospective teachers have to realize that their communicative competence is completely related to their instructional communication skills essential for the effectiveness and success in teaching and learning processes, establishing good relationships with their students and effective and interactive learning environment in the classroom. The purpose of this paper is to review recent research on instructional communication and discuss the implications of this research for EFL instruction. The discussion tries to find answers for the following theoretical questions: What is instructional/ classroom communication? What is the instructional communication model? What are the instructional communication skills required for EFL prospective teachers? And what is the importance of implementing instructional communication skills in EFL classrooms? Therefore, the present descriptive study recommends some instructional communication skills which can be adopted by EFL prospective, in-service teachers and even teachers of other subject matters for improving their instructional communication in the classrooms.

Keywords: Instructional/ Classroom Communication, Instructional Communication Skills, and EFL Prospective Teachers/StudentTeachers. 


\section{Introduction}

Teaching is an activity that is based on interaction between the teacher and the learner. Teaching and learning in the classrooms is a communicative process. Teachers communicate with students; and students communicate with their peers and with the teacher. Teachers and students communication with each other affects instruction and learning processes in the classroom. There is no teaching without communication. The difference between knowing and teaching is communication in the classroom. Hence, the predominant goal is to teach teachers about communication principles in classroom settings to enhance student learning (McCroskey \&Richmond, 1992, p.217; and Woods, 2007, p.854).

Later, Valencic, McCroskey and Richmond (2005, p.1) point out that there are three essential components of instruction: course content, pedagogy, and classroom/ instructional communication. This involves determining the general curriculum of the area of study, determining the content which will be addressed in an instructional event (a course, a unit, a workshop), and determining the way the content will be communicated. Most of these decisions (particularly those dealing with curriculum and content) will be made by educational specialists, yet most decisions in most instructional contexts regarding instructional communication are made by the actual instructor (teacher). Different instructors, dealing with the same curriculum and the same content, may choose to communicate with their students differently. The way they communicate is projected as a major factor in student learning.

According to Ihmeideh, Al-Omari and Al-Dababneh (2010, p.5), and Rajab and Che Abas (2010, p.15), teachers need excellent instructional communication skills to succeed in their profession. They believe that interpersonal, written and oral communication facilitates the accomplishment of teaching tasks, requirements and responsibilities effectively. Additionally, Erbay, Omeroglu and 
Cagdas (2012, p.3165) and Goolamhossen (2013, p.7) agree that one of the essential factors for EFL education to succeed and meet expectations is preparing teachers who have effective classroom/ instructional communication skills. This implies that classroom/ instructional communication is an essential medium not only in conveying information and instruction to the students, but also as core catalyst to create and maintain interaction between the learner and various elements of teaching/learning environment.

Therefore, the present study tries to advocate EFL prospective teachers' need to develop their instructional communication skills not only as a means for controlling and facilitating classroom activities, but also as an integral part of the course content and input materials. Therefore, teacher education programs have to guarantee the development of teachers' instructional communication skills.

\section{Instructional/ Classroom Communication}

Buhler (2000, p.2) suggests that there are two ways to approach the challenge of increased classroom communication; one is to allow for more opportunities to talk, and the other is to improve the quality of the teaching interactions that can occur. Hence, Buhler examined the effects of a communication program on the communication proficiencies used by first-grade students and their classroom teacher in Putnam County, New York. The participants in this investigation consisted of a group of 20 first-grade students (10 girls and 10 boys) and their classroom teacher. He investigated the communication strategies students and their teachers use before, at midpoint, and after the ten-week instructional communication program, such as, active listening including using habits such as eye contact, head nodding, asking topical questions, commenting, clarifying, verifying and role playing. The findings showed that a whole-class communication program led to building the foundations for increased competency in effective classroom communication with peers and their teachers; and that students could discover from their 
teachers the different types of speech genres necessary to meet the needs of various social situations.

Later, Mottet, Richmond, and McCroskey (2006, p.4), and Myers (2010, p.149) state that for over 30 years, researchers in the field of communication have examined teaching and learning as a communication process with the goal of enhancing teaching effectiveness and student learning. This area of study known as instructional communication examines teaching and learning using communication theory and research conclusions to explain, predict, and control instructional outcomes. Much of that work has focused on establishing relationships between teacher characteristics and student learning. Therefore, instructional communication is the process by which teachers and students stimulate meanings in the minds of each other using verbal and nonverbal messages. Instructional communication is recognized and acknowledged as a transactional process in which teachers and students mutually influence each other with their verbal and nonverbal messages that result in positive educational outcomes.

In addition, Akers and Johnson (2006, p.1), and Wrench, Richmond and Gorhann (2009, p.22) define instructional communication as the study of communication in the classroom. It is the investigation of the role of communication in the teaching of all subjects at all levels. This entails teacher characteristics (e.g. clarity and immediacy), student characteristics (e.g. learning styles), instructional methods, the pedagogy of communication in general, and student- teacher relationships.

Mathis' study (2006) explored the constructs of instructional/ classroom communication of the trainers that impact trainees' motivation and delivery of learning, Mathis mentioned four areas of appropriate instructional communication behaviors: clarity; enthusiasm; interaction; and verbal and nonverbal immediacy which 
have improved trainees' motivation, delivery of learning, and achieved learning outcomes. This paper illustrated how motivation and immediacy, and effective instructional behaviors (clarity, enthusiasm, and interaction) have been shown to increase cognitive, affective, and behavior learning and transfer of learning. There was a positive correlation between both teacher verbal and nonverbal immediacy and motivation and learning.

Mottet, Garza, Beebe, Houser, Jurrells, and Furler (2008) examined how students' perceptions of their teachers' instructional communication behaviors (nonverbal immediacy, clarity, content relevance, and teacher confirmation) were related to their affective learning in math and science. A survey was used to collect perceptions from 497 ninth-grade students. Results indicated that Teacher nonverbal immediacy, clarity, confirmation and content relevance behaviors are positively related with students' math/science affective learning outcomes.

Barad (2009, p.6), and Wrench, Richmond and Gorhann (2009, p.17-18) assert that although teaching is generally considered $50 \%$ knowledge and 50\% classroom communication skills, one of the most neglected aspects of teacher training is thorough preparation in the diverse instructional communication skills that are needed by good teachers in today's schools. For effective classroom communication skills, teachers have to consider six important points with their students: (a) Positive Motivation, where teachers create interest, enthusiasm, remove fear and inhibition. (b) Effective Body Language, where teachers use gestures, body movement with verbal skills e.g. (never sit and teach but move in aisles). (c) Sense of Humor, where teachers do not confuse dirty jokes with humor. (d) Understanding the Students, where teachers prefer dialogue over monologue and listen to students' opinion. (e) Team Formation, helps in mutual understanding among students as well as teachers. 
And (f) Technical skills, where the teachers use the latest technotools for teaching.

Additionally, Ismail (2009, p.37) and Thaahaveettil (2012, p.1) explain that teaching and learning processes require communication; and most classroom activities involve communication. Effective classroom communication ensures that learning takes place. Thus, all elements of communication either verbal or non-verbal communication within the classroom setting should be observed.

Therefore, Ismail (2009) investigated the effects of classroom communication on students' academic performance at International Islamic University Malaysia. The purpose of the study was to observe differences in patterns and communication practices between an excellent and an average lecturer and to see if any relationship existed between their classroom communication practices and students' academic performance. A survey was conducted with the main aim of gathering students' opinions regarding the importance of classroom communication. The survey was divided into five different dimensions. The five different dimensions were students' views of lecturers' response in the classroom, students' views of lecturers' initiations in the classroom, students' views of their classroom communication practices, students' views of ideal classroom communication practices, and students' views of the effects of classroom communication practices. The study showed that almost all students in both sections agreed on the importance of classroom communication. They believed that lecturers should be able to communicate effectively during lectures. Being an exceptional communicator is an indicator of an outstanding lecturer. The findings of the study showed that effective classroom communication is important in ensuring that teaching and learning take place.

Allan (2011) examined how college professors can improve their communication skills inside the classroom. A qualitative study 
analyzing written interviews completed by 19 college professors in Florida was conducted. This thesis addressed four main areas related to classroom communication skills (1) how to build a positive community inside the classroom, (2) how to have an interactive and engaging delivery, (3) how to develop a compelling oral presentation, and (4) how to focus on more active listening and less instructor- dominated talk. The findings of this study revealed the importance of communication skills in the higher education classroom.

Bee's study (2012) examined Singapore pre- service teachers' perception of their communicative strengths and weaknesses that influence their classroom practice. The pre-service teachers were invited to write about their perceived strengths and weaknesses in communication skills during and at the end of the program. This study involved 35 pre-service teachers; the points identified by the 35 reflection journals of the pre-service teachers as their communicative strengths and weaknesses were analyzed. The results of this study showed the importance of possessing effective communication skills in their delivery of subject content in the classroom and that a teacher should have confidence in delivery, able to explain ideas, theories in a clear and coherent way, relate to audience in an appropriate manner, and also be an active listener.

Maurine, Indoshi, Okwach and Osodo (2012) indicated that classroom communication plays a central role in language teaching and learning process. This study sought to establish the nature of communication process in Kiswahili classrooms with regard to factors of learner's attitude, teaching style, feedback and learning environment. The study sample was composed of 25 Kiswahili teachers and 317 students from 32 secondary schools in Hamisi District, Kenya. Direct classroom observation was used as the approach to data collection. The study found that teachers rarely accepted students' feelings and were least concerned with the mood of the students during Kiswahili lessons. Most Kiswahili classrooms 
were also seen to be dominated with teachers using the lecture method and in few instances asking students questions and students responding to what had been asked by their teachers. The results of this study assisted teachers in improving their classroom communication to promote students' academic achievement.

Similarly, Glomo- Narzoles (2013) investigated the correlation between classroom communication climate and communicative linguistic competence. The participants of this study were 180 university students, who were in their senior years. The findings revealed that the students who perceived classroom communication climate as supportive; were in classrooms that allowed students' flexibility, experimentation, and creativity, understanding and listening to the students, respecting their feelings and acknowledging their individual differences. This atmosphere in their classrooms made them feel secure; thus, their communicative linguistic competence was improved. In other words, there was a significant relationship between classroom communication climate and communicative linguistic competence of students.

Goolamhossen (2013) analyzed the significance of effective communication skills for good teaching for the pre-service secondary teachers in Mauritius Institute of Education. This study involved 50 pre-service teachers. The class met for 3 hours a week during a 15-week semester for the module in communication skills. There were 45 respondents and 42 reflection journals were analyzed. The results of the study showed that the pre-service secondary teachers tended to feel strongly that the tone used and the body language are important for giving instructions and servicing their subjects at schools. The reflections from the pre-service teachers' journals demonstrated that the communication course definitely had an impact in their self-confidence when they had to perform in class. The pre-service teachers claimed that they are equipped to use a wider scope of communication skills in their teaching practicum. 
Winters' research (2014) recognized the importance of instructional communication between students and faculty instructor in the classroom environment. Nonverbal immediacy, confirmation, and caring were explored as instructional communication behaviors that influence undergraduate college classrooms. The sample consisted of eight undergraduate students at fourth year university in Northern California. Results showed that instructors exhibiting a friendly mood, showing happiness, approachability, and flexibility are more likely to create a positive communication climate, and that the lack of verbal and nonverbal instructor communication reflecting the lack of desire to interact with students led to a more negative and defensive communication climate.

To sum up, based on the findings of the previous studies, the study of instructional communication is concerned with communication that links teaching with learning. Examining this phenomenon might include a number of variables that fall into three clusters: teaching, learning, and communication. In the teaching cluster, the variables might include teacher self-efficacy, teaching satisfaction, and motivation to teach. In the learning cluster, the variables might include student learning compliance, and motivation. In the communication cluster, the variables might include teacher and students' use of verbal and nonverbal message, such as nonverbal immediacy, affinity-seeking, humor, clarity, and compliance gaining strategies. Instructional/ Classroom communication relates to enhancing the teaching performance and the learning situation to support the students' learning and ensure that an effective and interactive classroom atmosphere is generated where the most effective learning takes place from all of the students. 


\section{Instructional Communication Theory}

According to Valencic, McCroskey and Richmond (2005, p.1), Beebe and Mottet (2009, p.1), and Wrench, Richmond, and Gorhann (2009, p.22), the instructional communication discipline has two traditions that influence how communication researchers study communication between teachers and students which are the rhetorical and the relational traditions.

\section{The Rhetorical Approach to Instructional Communication}

From a rhetorical perspective, McCroskey, Valencic, and Richmond (2004, p.197- 198); Valencic, McCroskey and Richmond (2005, p.1); Beebe and Mottet (2009, p.1); and Wrench, Richmond and Gorhann, (2009, p.22) confirm that teachers use verbal and nonverbal messages with the intent to influence or persuade students. To persuade is to develop messages that change or reinforce attitudes, beliefs, values, or behaviors. The function of rhetorical communication is to get students do what the teacher wants or needs them to do and/or think in order to persuade them. The rhetorical function of communication is teacher centered. The focus is on how the source of the message intentionally attempts to achieve a specific outcome. In the case of teachers communicating with students, the desired outcome is learning.

Therefore, the rhetorical approach to instructional communication assumes a process-product view of teacher and student communication. Researchers using the process-product paradigm study the teaching and learning process (including the messages teachers and students use to influence each other) and then measure the product of learning. The learning product includes how much students learned, as reflected in test scores, students' own perceptions of how much they learned, as well as students' affective response to the learning process. 


\section{The Relational Approach to Instructional Communication}

According to McCroskey, Valencic, and Richmond (2004, p.197- 198); Valencic, McCroskey and Richmond (2005, p.1); Beebe and Mottet (2009,1); and Wrench, Richmond and Gorhann, (2009, p.22), there is a second communication perspective that examines instructional communication as a relational process in which both teachers and students mutually create and use verbal and nonverbal messages to establish a relationship with one other.

From a relational perspective, rather than focusing exclusively on message content and behavioral outcomes, teachers and students are concerned with the emotions and feelings that are a part of the teaching and learning process. The relational perspective of communication, with its emphasis on affective or emotional responses, draws on contemporary models of communication in which meaning is mutually created and shared between individuals. In essence, the relational approach focuses on how teachers and students perceive and affectively respond to each other, which influences teachers' motivation to teach and students' motivation to learn.

There is a major emphasis of relational communication research on teachers' and students' use and interpretation of nonverbal messages. Nonverbal messages are those behaviors, other than written or spoken language, which create meaning for students. Nonverbal cues such as eye contact, posture, facial expressions, and gestures stimulate the majority of the emotional and social meaning in messages. Teachers who are nonverbally expressive or immediate (by establishing eye contact, smiling, using gestures, and moving closer to students) in the classroom positively influence students' liking for teachers, motivation to learn, and perceived learning.

Mottet, Richmond, and McCroskey (2006, p.285) conclude that from a rhetorical communication perspective, the instructional 
communication is teacher- directed. Instructors use verbal and nonverbal messages with the intention of influencing or persuading students. Teachers persuade or influence student- learning through the message. Meanwhile, from a relational perspective, the communication process is more collaborative. Instructors and students mutually co-create and use verbal and nonverbal messages to influence learning outcomes; instructors and students mutually influence each other through the relationship.

\section{The General Model of Instructional Communication (2004)}

McCroskey, Valencic, and Richmond (2004, p.197- 210) develop a general model of instructional communication. This model posits that an instructor's verbal and nonverbal communication behaviors lead to student perceptions of the instructor that in turn influence instructional outcomes. There are six essential components of this model of instruction: (1) teachers' verbal and nonverbal communication behaviors, (2) teachers' source credibility behaviors, (3) teachers' task attractiveness, (4) instructional outcomes, (5) teachers' temperament, and (6) the instructional environment. The components of the model will be discussed in the following:

\section{Teacher's Verbal and Nonverbal Communication Behaviors}

Teacher communication behaviors introduce considerable variance into the instructional process. What teachers say and what they do nonverbally constitutes a continuous stream of messages which impact the meanings stimulated in students' minds. Typically, individual teachers tend to have consistent verbal and nonverbal communication behavior patterns (what the teacher says and how he/ she says it) which are observable by students. Teachers' verbal and non-verbal communication behaviors can be measured throughout 
Teacher's Verbal and Nonverbal Immediacy, Assertiveness, and Responsiveness variables.

For many years, teacher's immediacy is the focus of a great deal of instructional communication research. In order for teachers to communicate effectively, teachers need to be aware of their verbal and nonverbal behaviors. According to Johnson and McCroskey (2004, p.61), Saechou (2005, p.15); Faylor, Beebe, Houser, and Mottet (2008, p.147), Shu-Fang and Aust (2008, p.481), immediacy consists of nonverbal and verbal communication behaviors. Immediacy verbal behaviors (e.g., using humor or personal examples, praising student work, getting feedback, or even calling students by name) and the nonverbal immediacy (e.g., eye contact, smiling, positive head nods). Both teachers' nonverbal and verbal immediacy behaviors have shown to have a positive influence on students' learning. Teachers might be immediate for a number of reasons: to show concern for students' needs, to initiate communication with students, or even to take control of a classroom situation in order to achieve a goal. Teachers who engage in immediate verbal and nonverbal behaviors have potentially more influence over students, an influence that may aid those teachers in accomplishing their goals; as verbal and nonverbal immediacy tends to evoke more communication and liking from their students.

Numerous studies such as Chesebro and McCroskey (2001), Saechou (2005), Tabasco (2007), Shu-Fang and Aust (2008), Velez and Cano (2008), Baker (2010), Ozmen (2011), and Hughes (2014) have found that teacher immediacy has a positive impact on student learning. Teacher immediacy increases student learning and is associated with a decrease in student learning loss, teachers would benefit from attempting to incorporate more immediate communication into their instruction to increase affective, cognitive, and behavioral learning. 
In addition, Singhal and Nagao (1993, 6), and Jacennik (2005, p.43) assert that both Assertiveness and Responsiveness are desirable behavioral traits closely related to communicative competence. Both assertiveness and responsiveness are indicators of interpersonal communication competence which is defined as the ability of interactants to choose among available communication behaviors in order that they may successfully accomplish their interpersonal goals.

According to Jacennik (2005, p.44), Motet, Richmond, and McCroskey (2006, p.75), and Runcan, Goian and Tiru (2012, p.187), assertiveness is the capacity to make requests; to actively disagree; to express positive or negative personal rights and feelings; to initiate, maintain, or disengage from conversations; and to stand up for oneself without attacking another. Assertiveness is differentiated from aggressiveness in communication, the main difference being respecting the rights of others to communicate. Furthermore, assertiveness is also differentiated from responsiveness defined as the capacity to be sensitive to the communication needs of others, to be seen as a good listener. Assertiveness is also the practice of behaviors which enables individuals to act in their best interest, or stand up for themselves without undue anxiety, or to express their rights without denying the rights of others.

\section{Teacher's Source Credibility Behaviors}

Russ, Simonds and Hunt (2002, p.312), Banfield, Richmond and McCroskey (2006, p.65), Zhang and Sapp (2009, p.87), Freeman (2011, p.2), and Teven (2012, p.1-2) believe that credibility is particularly important in the instructional communication context. In the classroom, the teacher is a central figure and the primary source of messages and information. If students do not place trust in their teachers, they may not make the investment in the relationship and in the learning process. Therefore, from the initial meeting between the students and the teacher until the course ends, it is important for 
teachers to both establish and maintain the perception of credibility. Teacher source credibility is considered to be a perception that students have of their teachers based on the observed communication behaviors of the teacher and consists of three dimensions: competence, trustworthiness, and goodwill. Competence consists of possessing knowledge or expertise of a particular subject. Competent teachers explain complex material well, have good classroom management skills, have the ability to answer student questions, and communicate effectively. Trustworthiness is the degree to which students trust their teachers. Trustworthy teachers offer rational explanations for grading, treat students fairly, give immediate feedback, and never embarrass students or are verbally abusive towards students. Goodwill, or caring, is the extent to which students perceive their teachers as caring for them and having their best interests at heart. Caring teachers have the ability to be empathic (i.e., the ability to identify with another student's situation or feelings), understanding (i.e., the ability to comprehend another student's ideas, feelings, and needs), and responsive (i.e., being other-oriented and having sensitivity toward others).

\section{Teacher's Task Attractiveness}

McCroskey, Richmond, and McCroskey (2006, p.2), and Banfield, Richmond and McCroskey (2006, p.65) developed a frequently used instrument for measuring three dimensions of interpersonal attraction. The scales are designed to indicate how attractive we find another person to be. Interpersonal attraction was characterized by three dimensions: (a) a social dimension; (b) a task dimension; and (c) a physical dimension. The researchers concluded that perceptions of attraction were responsible for both increased communication and interpersonal influence. 


\section{Instructional Outcomes}

According to, McCroskey, Valencic, and Richmond (2004, p.199), the primary outcomes of instructional communication are concerned with achieving learning cognitive, affective, and behavioral outcomes in the classroom. Many other outcomes can also occur, but they usually are incidental and not of central concern to the instructional communication process. The instructional outcomes can be measured throughout affective learning, cognitive learning loss, and the students' teacher- evaluation variables.

Revised Bloom's Taxonomy (1956 cited in Krathwohl, 2002, p.215), Wrench and McCroskey (2008, p.275) discuss that there were three domains of learning important for educational researchers to understand: cognitive, affective, and behavioral/ psychomotor. Cognitive learning domain includes those objectives which deal with the recall or recognition of knowledge and the development of intellectual abilities and skills. According to the revised Bloom's taxonomy, cognitive learning could be organized into six major classes with the first exhibiting the lowest levels of learning and the sixth exhibiting the highest level of learning: 1) remember, 2) understand, 3) apply, 4) analyze, 5) evaluate, and 6) create. Research in the field of instructional communication, according to Wrench and McCroskey (2008, p.276), has consistently shown that measuring a student's belief of her or his own cognitive learning is important for ascertaining the impact of instructional communication.

Furthermore, the affective domain of learning refers to objectives which emphasize a feeling tone, an emotion, or a degree of acceptance or rejection. Affective learning is learning about interests, attitudes, appreciations, values, emotional sets or biases. There is also taxonomy of educational objectives for the affective domain: 1) receiving, 2) responding, 3) valuing, 4) organization, and 5) characterization. According to Wrench and McCroskey (2008, p.276), affective learning has provided a considerable amount of 
research examining classroom communication. Affective learning occurs when learners take ownership of their learning and is manifested when students enact behaviors that demonstrate that they respect, appreciate, and value the knowledge and skills they are acquiring. Affective learners ultimately become internally motivated instead of externally motivated. Research has also shown that affective learning can substantially predict cognitive learning in the classroom.

The behavioral/ psychomotor learning is defined as learning that emphasizes some muscular or motor skill, some manipulation of material objects, or some act which requires neuromuscular coordination. Specifically, psychomotor or behavioral learning focuses on an individual's ability to enact the physical parts of specific behaviors. While there is not a specific taxonomy of psychomotor learning, McCroskey, Richmond, and McCroskey (2006, p.2) write that there is a range of psychomotor learning. At the low levels of psychomotor learning, are simple hand-eye coordination skills, and at the more advanced levels there is students' role- playing.

According to Teven and McCroskey (1996, p.8), Chesebro and McCroskey (2001, p.298), Waldeck (2007, p.422), and Baker (2010, p.9), the Learning Loss Scale has played a key role in establishing knowledge about instructional communication; they suggested that students' perceptions of cognitive learning were assessed by their responses on two scales designed by Richmond, McCroskey, Kearney, and Plax (1987). The measure asked students to indicate how much they felt they learned in the class on which they were reporting and how much they believed they could have learned had they had an ideal instructor. Scores from item one are subtracted from item two to obtain a "learning loss" score. The students were asked to respond to two questions: On a scale of 0-9, how much did the students learn in this class, with 0 meaning the students learned nothing and 9 meaning the students learned more than in any other class they have had, and how much do the students think they could 
have learned in the class where they had the ideal instructor. By subtracting the score on the first scale from the score on the second, a variable labeled "learning loss" was created.

\section{Instructional Environment}

McCroskey, Valencic, and Richmond (2004, p.197- 210) declare that the environment includes such elements as the nature of the institution hosting the instruction, the nature of the classroom, the culture of the institution (and the surrounding population), the level of instruction (elementary through graduate school), the physical and social climate in which are the institution exists, transitory factors (e.g., political environment, presence of athletic programs, size of class), and many other elements. Since there are no two instructional environments which are exactly alike; and most of these environmental factors are beyond the control of the teacher or the students; therefore, most of the variance created by the environment will function as error variance in the testing of instructional communication theories. All elements of the environment are accepted as error variance. Therefore, the environmental factor is executed.

\section{Teacher's Temperament}

There is a strong link between teachers' temperament and teachers' communication behavior. Teachers' temperament refers to the effect of the teacher's temperament on the students' learning process. Teacher's temperament can be measured by the short-form, self-report measures for the BIG THREE Temperament Variables advanced by Eysenck (1990): Extraversion, Neuroticism, and Psychoticism. McCroskey, Heisel, and Richmond (2001, p.360-366) indicate that teacher's temperament is a fundamental component of the instructional process and has been found to be important in the instructional environment. They show strong associations between Eysenck's Big Three Personality Structure (Extraversion, 
Neuroticism, and Psychoticism) and instructional communication variables. They represent biologically rooted individual differences in temperament which impacts the ways in which people interact. Teacher temperament precedes teachers' responses to social interaction within the school environment. Temperament is believed to explain why some individual teachers respond differently to stress and experience more burnout than others.

Eysenck (1990 cited in Teven, 2007, p.386) explained extraversion as teacher's cooperativeness, sociability, and responsiveness in high stimulus situations. Extraversion is related to sociability, assertiveness, activity, and positive affect. Extraverts tend to be positive, happy and optimistic. Teachers possessing this trait would tend to be positive, sociable, and outgoing in how they relate with students in the classroom environment. Given their strong, positive orientation toward students, extraverted teachers would likely care about them. Eysenck defines Neuroticism as an enduring tendency to experience negative emotional states. Neuroticism is a vulnerable personality factor for depression. Teachers scoring high on the neuroticism domain of personality would likely experience negative emotions including fear, disgust, depression, and anxiety. These teachers would not cope well with stress, thereby making them more likely to experience burnout. Teachers who do not tend to experience such negative emotional states can be optimistic, assured, steady, and confident.

In addition, Eysenck points out that Psychoticim refers to both agreeableness and conscientiousness. Agreeableness refers to an individual difference in concern with cooperation and social harmony. Agreeableness is a tendency to be compassionate and cooperative. Within work groups, the agreeable participant is likely to support other team members' viewpoints and experiences. Agreeable teachers seek to establish and maintain positive relationships with those in their immediate environment and are supportive of students. 


\section{Instructional Communication Skills}

According to Valencic, McCroskey, and Richmond (2005, p.1), Mottet, Richmond and McCroskey (2006, p.283-300), and Beebe and Mottet (2009, p.3- 9), the rhetorical instructional research variables include teacher credibility, task attractiveness, clarity, and instructional humor. While, research variables that have relational communication applications include immediacy, affinity-seeking, confirmation, and behavioral alternation techniques. These eight instructional communication research variables will be highlighted as follows:

\section{Teacher's Credibility}

Credibility is the perception of character, intelligence, and goodwill that a teacher is perceived to possess. Teachers who are perceived as highly credible are viewed as more persuasive, organized, and skilled in responding to questions and are overall perceived as more competent than are teachers who are not perceived to be credible. In the context of the classroom, credibility is the overall perception that students have toward a teacher in terms of the person being believable, knowledgeable, trustworthy, and dynamic. As in other speaking situations, teachers who are perceived as credible have more influence over students than teachers who are not perceived as credible.

Myers and Martin (2006, p.67-88) summarize research conclusions and applications of teacher's credibility as follows:

- Teachers who have higher perceived credibility are also perceived as more effective teachers.

- Students who perceive their teachers as having high credibility are more motivated to learn than students who perceive their teachers as having low credibility. 
- Students who perceive their teachers as having high credibility report higher cognitive learning than students who perceive their teachers as having low credibility.

- Students who perceive their teachers as having high credibility report higher affective learning than students who perceive their teachers as having low credibility.

- Students who perceive their teachers as having high credibility are more likely to participate in class discussions than students who perceive their teachers as having low credibility.

\section{Teacher's Clarity}

Sidelinger and McCroskey (1997, p.1-2) point out that teacher's clarity is related to the verbal aspects of teachers' communication behaviors. Clarity has been taken to include such behaviors as expressiveness, message clarity, explaining effectiveness, teacher explanation, structuring, direct instruction, explicit teaching, teacher elaboration, message fidelity, task structuring, and coaching and scaffolding. As teacher clarity increases, the student's learning is more likely to be enhanced and the student's evaluation of the teacher is more likely to be positive. Teacher clarity appears to be a key component in facilitating both student and teacher success in the instructional environment.

Ginsberg $(2004$, p.23) state that clarity is the process by which an instructor is able to effectively stimulate the desired meaning of course content in the minds of students through the use of appropriately-structured verbal and nonverbal messages. Clarity includes soliciting questions from the students, providing examples, using clear, concise language when introducing material, speak articulately and audibly, stay on task without wandering to other topics, and use commonly understood vocabulary. When a teacher is clear, students comprehend the teacher's intended meaning better than when a teacher is not clear. Also, Mottet, Richmond, and McCroskey (2006, p.99) asserted that clarity is positively related to 


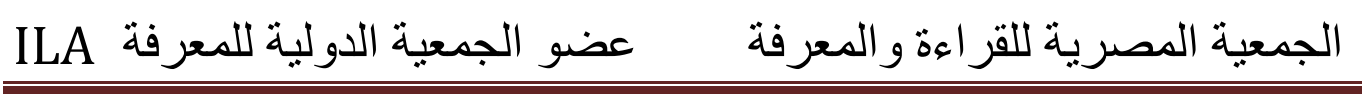

increased student state motivation to learn, positive affect, and perceived cognitive learning.

Chesebro and Wanzer (2006, p.89- 116), summarize research conclusions about teacher clarity as follows:

- Teachers who are perceived as clear are perceived as more effective teachers.

- Students who perceive their teachers as clear learn more than from teachers who are perceived as not clear.

- Teachers who are clear reduce students' fear or apprehension of communicating in the classroom.

- Teachers who are perceived as clear are liked more by their students, and students liked their course content more than that of teachers who are not perceived as clear.

\section{Teacher's Instructional Humor}

Beebe and Mottet (2009, p.3-9) refer to instructional humor as one communication tool that teachers can utilize to assist learning. Teacher's instructional humor has an effect on the emotional climate of a classroom. It creates a relaxed and friendly classroom environment. Appropriate humor includes humorous statements that are related (or sometimes unrelated) to course material, nonverbal expressions, self- deprecating humor, humorous props, sarcasm, puns, jokes, riddles, stories, situations, cartoons and unintentional humor. On the other hand, there are some kinds of humor that are generally perceived as inappropriate: humor at the expense of a student, swearing, racial stereotypes, or making light of very serious issues. "Making fun of students" is considered as the most inappropriate type of humor.

Truett's (2011) study findings at Texas Tech University (366 participants) displayed that students' perceptions of learning was greater when teachers incorporated related humor, and that the use of 


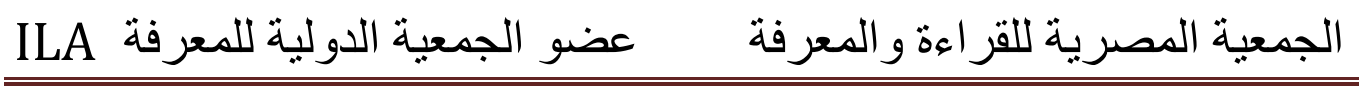

certain types of humor in lectures or discussions increases students' perceptions of learning.

Chesebro and Wanzer (2006, p.89- 116) reported research conclusions about instructional humor in the classroom as follows:

- Teachers who win awards for their teaching use moderate amounts of humor.

- Students do not prefer teachers who use an excessive amount of humor but do like teachers who use some humor when teaching.

- Students have individual differences and preferences for the amount and type of humor used by instructors.

\section{Teacher's Immediacy}

Mottet, Richmond and McCroskey (2006, p.283-300) review that teacher immediacy is one of the most researched instructional communication variables. Immediacy is a perception of physical and psychological closeness. Such closeness, either literal or psychological, has a major effect on the perceived quality of a communication relationship. Immediacy consists of communication behaviors that enhance closeness to and nonverbal interaction with another. Perceptions of immediacy expressed through behaviors such as forward body leans, head nods, and eye contact, which enhance relational development in interpersonal communication situations, are also applicable to relationship between teachers and students. Teachers who use immediacy behaviors resulted in students who have overall a more positive attitude toward the instructor and the course content.

Hence, Ginsberg's (2004) research attempted to identify faculty characteristics that were associated with the instructional communication characteristics of immediacy and clarity. It sought to identify how and why college faculty members develop immediacy and clarity. This study was conducted at two public, comprehensive colleges and universities. A group of 11 teachers were chosen. The 


\section{الجمعية المصرية للقر اعة والمعرفة عضو الجمعية الدولية للمعرفة ILA}

findings assert that the students of highly immediate and clear university teachers reported improved learning and motivation.

Witt, Wheeless, and Allen (2004, p.184- 207) and Richmond, Lane, and McCroskey (2006, p.167- 194) report some of the most important findings for teacher's immediacy:

- Teacher verbal and nonverbal immediacy increases student cognitive learning. Teachers' use of immediacy behaviors helps their students learn.

- Teacher verbal and nonverbal immediacy increases student affective learning. Students have more positive feelings about both the teacher and the course content.

- Teacher verbal and nonverbal immediacy is significantly and positively related to perceptions of teacher clarity. Teachers who are immediate are perceived as providing more clear instruction than teachers who are not immediate.

- Teacher nonverbal immediacy increases students' perceptions of teacher effectiveness.

- Teacher nonverbal immediacy plays a mediating role in the reception and effectiveness of teacher control strategies.

- Teacher immediacy produces a reciprocal liking among teachers and students.

Therefore, Asiri (2013) conducted a quasi-experimental study to investigate the effects of instructor's verbal and nonverbal immediacy skills on students ${ }^{6}$ communication (i.e., class participation) and learning outcomes (i.e., state motivation, communication satisfaction, affective learning, and cognitive learning). The study sampled 115 undergraduate students at King Khalid University in Saudi Arabia. The participants were distributed into three groups: two control groups and one treatment group. The findings of this study strengthened that generally, instructor verbal and nonverbal immediacy skills cause positive student communication and learning outcomes. Instructor's immediacy 


\section{الجمعية المصرية للقر اعة والمعرفة عضو الجمعية الدولية للمعرفة المي}

appeared to be a significant factor in developing interpersonal relationships with students and promoting student communication and learning outcomes.

\section{Teacher's Affinity Seeking}

Richmond's study (1990) examined the effect of teacher immediacy and teacher use of affinity- seeking techniques on students' motivation toward studying course content. The subjects in this study were 366 undergraduate students enrolled in elective courses in communication in the university. This study suggested that the role of communication in the classroom is much more than simply the means of transmitting content and messages. It is the primary means by which, students' motivation is increased and as a result, learning enhanced.

Mottet, Richmond, and McCroskey (2006, p.196-207) point out that affinity-seeking behaviors are those verbal and nonverbal behaviors that are used to get the students like their teacher. It refers to a positive attitude toward another person. Evidence suggests that teachers who are liked by their students enhance the learning climate. Teachers' use of affinity-seeking, that is, specific behaviors that cause them to be liked, results in increased student affinity with both the teacher and the subject matter. Various teaching strategies which are associated with positive classroom relationships, increased learning, motivation, and overall positive climate include what follows:

- Facilitating enjoyment: The teacher purposefully works to increase student enjoyment of classroom activities, lectures, and assignments.

- Optimism: The teacher expresses a positive, hopeful, upbeat outlook.

- Assuming equality: The teacher minimizes status differences between teacher and students. 


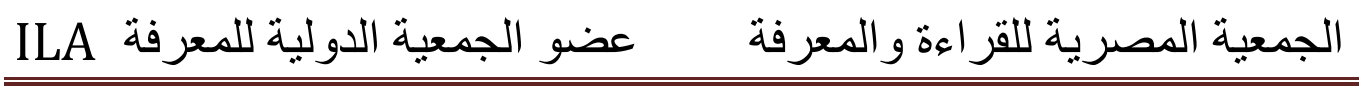

- Conversational rule keeping: Teachers are polite, don't interrupt students, and treat students with respect.

- Comfortable self: The teacher is confident, relaxed, and overall appears comfortable in the classroom.

- Dynamism: Teachers are enthusiastic and energetic.

- Eliciting others' disclosures: Teachers provide individual attention to students, invite students to talk about themselves, and then use the information they learn from students to compliment the student.

- Altruism: Teachers are helpful to students and go beyond expectations to assist students.

- Listening: Teachers listen without interrupting a student.

- Sensitivity: Teachers express caring, empathy, and warmth toward students.

Frymier and Wanzer (2006, p.195- 212) summarize some research applications about affinity seeking in the classroom as follows:

- Teachers who use affinity-seeking strategies are perceived to be more credible that is more knowledgeable, trustworthy, and dynamic than teachers who do not use affinity-seeking strategies.

- Teacher use of affinity-seeking strategies is moderately correlated with student motivation to learn.

- Teachers who evoke more positive feelings from students enhance the learning climate.

- Teachers who use selected affinity- seeking strategies enhance student liking toward the teacher and the subject matter.

\section{Teacher's Confirmation}

Ellis's study (2000) reported an initial attempt to explore the pedagogical role of perceived teacher confirmation in the college classroom in behavioral terms and explores relationships among perceived teacher confirmation, cognitive learning, and affective learning. Results for two samples $(\mathrm{N}=446, \mathrm{~N}=303)$ indicated that 


\section{الجمعية المصرية للقراعة والمعرفة عضو الجمعية الدولية للمعرفة ILA}

teacher confirmation plays a significant role in college students' cognitive and affective learning.

Later, Goodboy (2007, p.1-5) asserts that one of the effective teaching behaviors that impacts learning and affect is teacher's confirmation. Teacher's confirmation is the process through which instructors communicate to students they are recognized and acknowledged as valuable and significant individuals. Although the study of confirmation is rooted in the interpersonal communication context, instructional scholars are beginning to assess the value of confirmation in the instructional communication context. The study of teacher confirmation is vital to student communication and learning outcomes for three reasons. First, confirming messages promote active student learning in the classroom. Second, perceptions of teacher confirmation may establish a supportive classroom climate by communicating instructor interest to students. Third, teacher confirmation messages signify a caring to know the students from the instructor.

Goodboy (2007), and Goodbye and Myers (2008) examined the effects of teacher's confirmation on both student communication behavior and learning outcomes in the college classroom, and suggested that students form positive perceptions of confirming instructors and reported increases in learning. Teacher confirmation leads to increases in positive student communication behavior (i.e., student communication motives, student participation).

Mottet, Garza, Beebe, Houser, Jurrells, and Furler's study (2008) examined how students' perceptions of their teachers' instructional communication behaviors were related to their affective learning in math and science. A survey was used to collect perceptions from 497 ninth-grade students. The results showed that students' perceptions of their math and science teachers' use of nonverbal immediacy, clarity and confirmation relevance behaviors positively affect their learning in math and science. 
Simmons' qualitative study (2011) sought to determine how interpersonal confirmation and disconfirmation are perceived in online distance learning courses at the community college level by determining the specific communication teacher behaviors that cause confirmation and disconfirmation perceived by their students. Simmon reported that confirmation and disconfirmation could be experienced through visual, tactile, and auditory modes. The results showed that confirmation and disconfirmation can be perceived in an online distance-learning course.

Meanwhile Edwards, Edwards, Torrens, and Beck (2011, p.2325); and Campbell, Eichhorn, Basch and Wolf (2012, p.499) indicate that recent studies by instructional communication scholars have focused on a variety of factors, including factors such as, teacher's immediacy, teachers' use of humor, and teachers' clarity. One type of teacher behavior that has not been examined adequately is teacher confirmation which is the transactional process by which teachers communicate to students that they are endorsed, recognized, and acknowledged as significant and valuable individuals. Therefore, Campbell, Eichhorn, Basch, and Wolf (2012) support the suggestion that future teacher need training in teacher confirmation skills.

\section{Behavioral Alteration Techniques (BATs)}

The researchers Roach, Richmond, and Mottet (2006, p.117136) have documented the techniques that had a more positive effect on student learning. Some of the more positive or pro-social BATs include (a) offering rewards, (b) appealing to enhanced self-esteem if students would perform certain behaviors (e.g., read the assignment), (c) expressing liking toward the student, (d) being responsive toward the student, and (e) noting that others have performed the same behavior and that the teacher has modeled the behavior. Thus, Teacher's use of BATs affects student motivation toward learning and exerts power over students. 


\section{Teacher's Task Attractiveness}

McCroskey, Richmond, and McCroskey (2006, p.1-26) and Aydin (2012, p.247-251) demonstrate that instructor attractiveness is also considered as an important construct regarding instructor's communication behaviors. According to the social psychologist, attractiveness or interpersonal attractiveness refers to the tendency of someone to have appreciation and positive feelings towards someone else. It is regarded as a determinant factor on the development and continuation of relations in social environments where interaction takes place. Based on interpersonal attractiveness, McCroskey, Richmond, and McCroskey (2006, p.20-21) develop a framework and measures to determine the interpersonal attractiveness in various settings. The framework suggests three dimensions of interpersonal attraction: a student's desire to work with the teacher (task attractiveness), to socialize with another person (social attractiveness), and attraction to another person based on physical appearance (physical attractiveness).

\section{Assessing Instructional Communication in the Classroom}

There are many previous studies such as McCroskey, Valencic, and Richmond, (2004); Mathis (2006); Faylor, Beebe, Houser, and Mottet (2008); Beebe and Mottet (2009) that aimed to develop evaluation instruments of the teachers' performance that includes valid and reliable instructional communication measures. These studies advocate using instructional communication measures to evaluate and assess instruction for the following reasons. Firstly, instructional researchers can easily use the items from the measures to address specific instructional communication necessities; secondly, with slight modification, the measures can be used as both a self-report assessment and as an other-report assessment; as in some situations, it may be beneficial to see how the instructor's selfreport of instructional communication behaviors differ from students' 
reports of the same behavior; and thirdly, instructional researchers or other experts can use the measures to assess the instructor's use of instructional communication.

\section{Assessing Rhetorical Communication Behaviors}

According to Mottet, Richmond, and McCroskey (2006, p.286289), the assessment of the rhetorical communication teacher's behaviors can be done through the following dimensions:

\section{Instructor Clarity Behaviors}

Instructor clarity has been defined as the process by which an instructor is able to effectively stimulate the desired meaning of course content and processes in the minds of students through the use of appropriately structured verbal and nonverbal messages. Teacher's clarity behaviors can be measured throughout the teacher clarity inventory (TCI).

\section{Instructor Content Relevance Behaviors}

Content relevance refers to students' perceptions of whether instructional course content satisfies students' personal needs, personal goals, and/ or career goals. A 12 item scale to measure teacher's use of relevance strategies in the classroom is featured to assess instructor content relevance behaviors.

\section{The Behavioral Alteration Techniques}

The behavioral alteration techniques and message typology includes a comprehensive list of compliance- gaining techniques and messages that instructors use in their attempts to influence students. An assessment instrument list of compliance- gaining techniques and messages used by teachers is used to assess instructor compliancegaining messages. 


\section{Instructor Credibility}

Instructor credibility is viewed as the attitude of a receiver that references the degree to which a source is seen to be believable. It is based on ethos (competence, trustworthiness, and goodwill), competence refers to the degree to which a teacher is perceived by students to be knowledgeable about a given subject; trustworthiness or character refers to the degree to which a teacher is trusted by students; and goodwill refers to the degree to which a teacher is perceived to be caring. A developed assessment instrument is featured to assess teacher's source credibility.

\section{Assessing Relational Communication Behaviors}

According to Mottet, Richmond, and McCroskey (2006, p.289297), the assessment of the relational communication teacher's behaviors can be done through the following dimensions:

\section{Instructor's Verbal and Nonverbal Immediacy Behaviors}

Verbal and Nonverbal immediacy behaviors are those linguistic and non- linguistic behaviors that enhance relational development and perceptions of physical and psychological closeness. Nonverbal immediacy behaviors can include forward body leans, head nods, eye contact, expressive gestures, and smiling. The verbal immediacy scale (VIS) is an assessment instrument to assess teacher's verbal immediacy behaviors. The nonverbal immediacy scale (NIS) is an assessment instrument to assess teacher's nonverbal immediacy behaviors.

\section{Instructor Affinity-Seeking Behaviors}

Affinity- seeking is the active social communicative process by which individuals attempt to get others to like and feel positive toward them. The affinity- seeking measurement instrument is reviewed in few previous studies such as Richmond (1990). 


\section{Instructor Misbehaviors}

Teacher misbehaviors are those behaviors identified by students that irritate, demotivate, or substantially distract them from learning. Teacher misbehaviors reflect student perceptions of teacher actions that interfere with learning, even if those teacher behaviors are unintentional or reflect personal attributes, such as a teacher's dialect or accent. There are three factors of teacher misbehaviors: incompetence, offensiveness, and indolence. Incompetent teachers engaged in a cluster of misbehaviors that indicate to students that they do not care about either the course or the student. Offensive teachers are characterized as mean, cruel, and ugly. Indolent teachers are characterized as being lazy and absent minded.

\section{Evaluating Instructional Communication Outcomes}

According to Mottet, Richmond, and McCroskey (2006, p.292302), teachers' verbal and nonverbal communication behaviors affect students and their learning outcomes.

\section{Assessing Student Outcomes}

Assessing student outcomes can be throughout the following items:

\section{a. Affective Learning}

It addresses students' attitudes, beliefs, values, and feelings about what they learn. Affective learning can be considered a more valid indicator of instructional effectiveness than cognitive learning.

\section{b. Cognitive Learning}

It focuses on the acquisition of knowledge and the ability to understand and use knowledge. To evaluate an individual instructor's impact on student cognitive learning, assessors are encouraged to use the instructor's exams as long as they are valid and reliable. There is also the cognitive learning measure through which researchers can 
measure the learning loss score which is considered to be an important item to refer to the effectiveness of the instructional communication process.

\section{c. Behavioral Learning}

It refers to, as psychomotor leaning, physical actions and the development of physical skills. If the instructor's course includes a behavioral component, assessors may want to evaluate the instructor's instructional communication effectiveness by evaluating student's behavioral learning.

\section{Assessing Teacher Outcomes}

\section{a. Teacher Self-Efficacy}

It is the extent to which the teacher believes he or she has the capacity to affect student performance.

\section{b. Teacher Job-Satisfaction}

It is the state of mind- determined by the extent to which the individual perceives his/ her job related needs being met.

\section{c. Teacher Motivation}

It is the teacher's internal state of readiness to take action or achieve a goal. It is a proponent state that energizes and guides behavior.

Finally, after reviewing previous literature concerning instructional communication skills and assessing instructional communication, the researcher summarizes the most wide spread instructional communication skills in educational studies as shown in the following figure: 
الجمعية المصرية للقر اعة والمعرفة عضو الجمعية الدولية للمعرفة

Figure 1. Instructional Communication Skills.

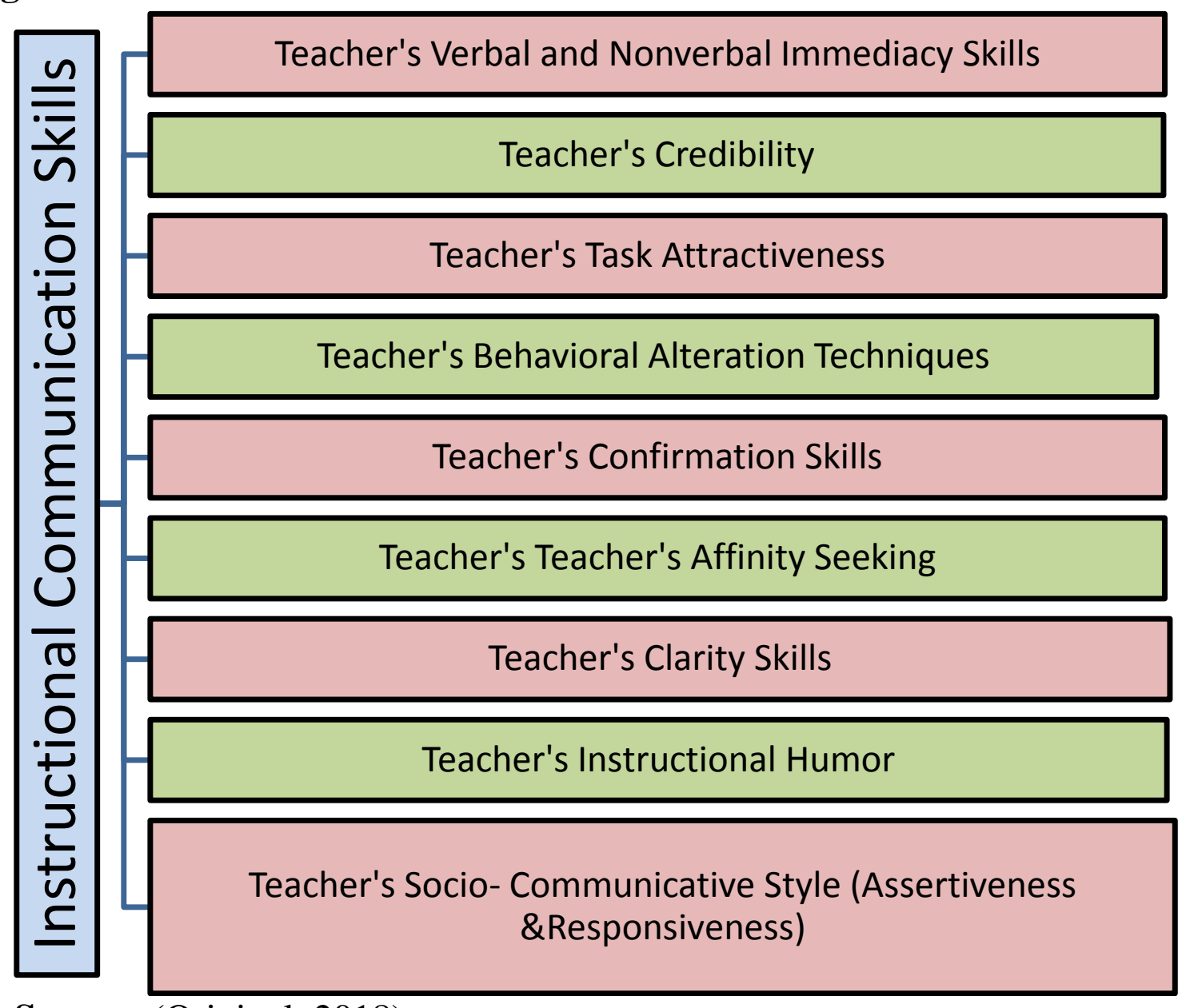

Source: (Original, 2018).

As shown in the previous figure, the instructional communication skills include teacher's immediacy, clarity, confirming, humor, credibility, task attractiveness, affinity-seeking, behavioral alteration techniques, assertiveness and responsiveness. 


\section{Instructional Communication and Effective EFL Classroom Interaction}

Dagarin (2004, pp.128- 129) point out that effective EFL classroom interaction has two implications. The first one concerns a pleasant atmosphere in the classroom with friendly relationships among the participants of the learning process. The second one encourages students to become effective communicators in a foreign language. This can be achieved through various ways: by implementing different student and teacher roles, by exposing students to a varied classroom organization, by employing a variety of activities, by helping students to express themselves and by encouraging their use of communication strategies. If the two implications are joined, teachers get a pleasant classroom atmosphere in which students are trying to communicate in the foreign language. In fact, interaction is the heart of communication; it is what communication is all about. Since the classroom is a community of some kind, there is the need to establish and maintain personal relationships. The teacher has to establish rapport with the class, and students form different sorts of relationships with the group and with the teacher. Interaction is mainly achieved by two means of resources: language and non-verbal means of expression. Non-verbal resources play just as important part as language does in the classroom. Students can obtain a lot of information from teacher's gestures and mime.

Therefore, EL-Fatihi (2006, p.2) reports that the new educational trend brought changes all over the teaching and learning process. Among these changes are the roles of both teacher and learner. The role of the teacher became a facilitator, counselor, and animator. These new roles require a change in the EFL classroom discourse. More importance is given to visual techniques and body language. Another change brought by the new trend is the focus of the EFL classroom. Communication became the pivotal focus of the 


\section{الجمعية المصرية للقراعة والمعرفة عضو الجمعية الدولية للمعرفة ILA}

teaching practice, that is to say more importance is given to interaction in the target language over grammatical formalism.

Boyanton (2007), using case study type of research, investigated the interpersonal communication patterns (studentteacher, student-student) in the college classroom, to identify the type of pattern which most benefits learning, and develop a theory to explain how to create this type of interpersonal communication. Two professors and four courses (two graduate courses and two undergraduate courses) were observed for three semesters. This research determined powerful interpersonal communication, the pattern of interpersonal communication which most benefits learning in the college classroom and factors that affect interpersonal communication in the educational field, such as the teacher's role, credibility, affect, and immediacy. And that powerful interpersonal communication requires four basic criteria: 1) communicators are able to communicate freely; 2) communicators are motivated to communicate; 3 ) communicators are fully engaged and use higherorder thinking skills during the communication process; and 4) communicators develop new or different understandings as a product of the communication.

Hsu, Watson, Lin, and Ho (2007, p.2-6) assert that instructional communication skills impact students' willingness toward classroom participation. Students' willingness to participate in EFL classroom activities is not only from speaking anxiety, communication incompetence, low self-confidence and lack of motivation, but also can be caused by a fearful environment that a teacher unknowingly creates. Students are motivated to talk and participate when teachers are responsive and caring. When teachers demonstrate an immediate attitude through verbal and nonverbal forms of communication, a supportive classroom climate is established where students feel encouraged and accepted. In a supportive classroom climate where a teacher creates an atmosphere of warmth, safety, acceptance, and 
genuineness with his or her students, the student becomes a more self-initiated, self-confident, self-directed, and less anxious learner.

Furthermore, Hsu (2010) investigated teachers' nonverbal immediacy behaviors in relation to students' motivation for learning English. A sample of 303 participants was drawn from a technology institution in central Taiwan. The results of the Pearson correlation indicated that teachers' nonverbal immediacy behaviors were correlated positively and significantly with students' motivation for learning English.

Pie (2013, p.668- 670) conclude that instructional communication is a process in which the teacher selects and arranges what the students are to learn (the content), decides how best to help them learn (the instructional strategy), and determines how success in learning will be determined and how the students' progress will be communicated by and to them. There is a dynamic interplay among the various elements of the process. In any content area, Pie asserted that what the teacher teaches should be selected with attention to cognitive (knowledge), affective (attitude), and psychomotor (skill) learning outcomes. These three domains of learning must be addressed when examining the content within teacher's classroom. Also, Instructional strategies are the ways in which teachers design their communication to teach the objectives to students. Students learn in different ways, and they are likely to have the greatest affect for things that are taught in the way they learn best. Varying instructional strategies is necessary to accomplish different levels and styles of learning. Most students should enjoy learning more when there are regular changes in class routine.

To sum up, EFL teachers should be aware that their instructional communication skills effectively and powerfully improve their teaching and enhance students' learning of English. Therefore, EFL teachers should be more sensitive in their English classrooms, knowing that their instructional communication skills can have a 
positive influence reducing students' anxiety in English learning, and result in effective learning outcomes.

\section{Conclusion and Recommendations}

This paper was conducted to give a theoretical overview on developing the instructional communication skills of EFL prospective teachers in the classrooms. Competent EFL teachers should have certain instructional communication skills to facilitate and motivate their students' learning, as long as the conventional teacher preparation and training programs usually concentrate on the basic famous teaching skills (such as stating learning objectives, using teaching strategies and aids, assessment, etc.). These skills almost advocate students' cognitive learning while ignore improving their affective and behavioral learning which mostly related to motivation and interaction in the learning process in the classroom. Researchers in education (e.g. McCroskey, Valencic \&Richmond, 2004; Ismail, 2009; Maurine, Indoshi, Okwach \&Osodo, 2012; and Glomo-Narzoles, 2013) have been interested in developing instructional/ classroom communication skills of EFL teachers through their preparation and training programs. McCroskey, Mottet and Richmond (2006) predicted that the instructional communication skills would become one of the most effective domains for teachers' preparation in the years to come for fostering students' involvement in learning process. However according to the researcher's best knowledge, there were no studies concerning instructional communication skills in the Egyptian EFL educational research context and this suggests new directions for researchers and educators.

According to EFL prospective and in-service teachers, the researcher recommends that implementing both the instructional communication skills is highly effective in improving their general teaching performance and the learning climate and outcomes in the EFL classrooms. The instructional communication skills positively 
support EFL teachers' and students' motivation, interaction and involvement in the classrooms. Awareness of the instructional communication skills will also encourage EFL teachers to develop their professionalism. Thus, they are expected to use instructional communication skills in the classroom to give feedback, to motivate learners, and have a good classroom management. All these professional qualities can be fostered by the positive use of instructional communication skills. The present study supports Allan's (2011) and Goolamhossen's (2013) recommendations for the teacher educators of the prospective teachers' preparation programs to include the instructional communication skills in the current programs beside the required conventional teaching skills to outcome competent and professional teachers.

Based on the previous research findings, both EFL pre-service and in-service teachers need excellent classroom/ instructional communication skills to succeed in their profession. They have to realize that their communicative competence is completely related to their instructional communication skills essential for the effectiveness and success in teaching and learning processes, and establishing good relationships with their students inside the classroom.

\section{Suggestions for Further Research}

When exploring the related literature, the researcher hardly encountered previous studies of direct relevance to the development of Egyptian EFL teachers' instructional communication skills. That is why the researcher believes that instructional communication is one of the neglected areas of teacher training/ preparation - despite its importance for successful teaching. Thus, the lack of research in this field justifies the need for further studies tackling this problem.

Therefore, the present paper support the need for further research in the area of instructional communication skills which are still very new and need more future studies in the Egyptian 
educational research context to confirm or disconfirm the discussion of the present paper. Hence, the researcher would like to suggest the following:

- Further research is needed to investigate the effectiveness of a teaching program in developing instructional communication skills of EFL in-service teachers.

- A study may be conducted to investigate the relationship between instructional communication skills and students' cognitive achievement and learning loss.

- Conducting a study that investigates the quality of teaching and performance skills presented in EFL teacher preparation programs in faculties of education.

- A study is needed to investigate the effectiveness of implementing different instructional communication skills on EFL students' achievement in classroom.

- A study could examine which skill among the instructional communication skills can be used most successfully and effectively to improve the EFL students' achievement.

- A study is needed to investigate attitudes and perceptions of the students towards their teachers who using instructional communication skills.

- A study is needed to investigate the effectiveness of teachers' preparation or professional development programs in improving prospective teachers' or in-service teachers' instructional communication skills with another subject matter. 


\section{الجمعية المصرية للقر اعة والمعرفة عضو الجمعية الدولية للمعرفة ILA}

\section{References}

Akers, A. \& Johnson, A. (2006). Instructional Communication: An Applied context. Retrieved March 27, 2014, from http://www.uky.edu

Allan, J.V. (2011). Improving Collage Professors' Communication Skills inside the Classroom: An Exploration Study (Master's Thesis, Florida Atlantic University). Available from Proquest Dissertation and Theses Database. (UMI NO. 1496225).

Asiri, A.A. (2013). The Impact of Instructor Immediacy on College Student Communication and Learning Outcomes in Saudi Arabia. (Doctoral Dissertation, College of Education, Victoria University, Australia). Retrieved March 7, 2018, from http://www. vuir.vu.edu.au

Aydin,I.E.(2012). Relationship between Affective Learning, Instructor Attractiveness and Instructor Evaluation in Video Conference-Based Distance Education Courses. The Turkish Online Journal of Educational Technology, 11 (4), 247-252

Baker, C.(2010). The Impact of Instructor Immediacy and Presence for on Line Student Affective Learning, Cognition, and Motivation. The Journal of Educators Online, 7(1), 1 - 30

Banfield, S.R., Richmond, V.P. \& McCroskey, J.C. (2006). The Effect of Teacher Misbehaviors on Teacher Credibility and Affect for the Teacher. Communication Education, 55(1), 63 - 72

Barad, D. (2009). Communication Skills for Teachers. Retrieved Feb 25, 2014, from http://www.slideshare.net

Bee, S.B. (2012). The Impact of Teachers' Communication Skills on Teaching: Reflections of Pre-Service Teachers on their Communication Strengths and Weaknesses. Humanizing Language Teaching, 14 (1), Retrieved March 2, 2014, from htpp://www.informaworld.com

Beebe, S.A. \& Mottet, T.P. (2009). Students and Teachers: $21^{\text {st }}$ Century Communication. Retrieved Nov 14, 2014, from http://www.sagereference.org

Boyanton, D. (2007). Creating Powerful Interpersonal Communication in the College Classroom. (Doctoral Dissertation, the Faculty of Curry School of Education, University of Virginia). Available from Proquest Dissertation and Theses Database. (UMI NO. 3282498). 
Buhler, H.C. (2000). Communication Strategies in a First - Grade Classroom: A collaborative Teaching Curriculum - Based Approach. (Doctoral Dissertation, the Graduate School of Education, Fordham University). Available from Bell \& Howell Information and Learning (UMI NO.9975340).

Campbell,L.; Eichhorn,K.; Basch, Ch.; \& Wolf,R. (2012).Exploring the Relationship between Teacher Confirmation, Gender, and Student Effort in the College Classroom. Human Communication: a Publication of the Pacific \&Asian Communication Association, 12(4), 447-464

Chesebro, J.C., \& McCroskey, J.C. (2001). The Relationship of Teacher Charity and Immediacy with Student State Receiver Apprehension, Affect, and Cognitive Learning. Communication Education, 50, 59 - 68

Chesebro, J.L., and Wanzer, M.B. (2006). Instructional Message Variables. In Mottet, T.P., Richmond, V.P. and McCroskey, J.C., Handbook of Instructional Communication: Rhetorical and Relational Perspectives (pp. 89 116). Boston: Allyn \& Bacon

Dagarin, M. (2004). Classroom Interaction and Communication Strategies in Learning English as a Foreign Language. English Language and Literature Teaching, ISSN $1581-8918,128$ - 139

Edwards, C., Edwards, A., Torrens, A., \& Beck, A. (2011). The Relationships between Teacher Confirmation, Classroom Community, Student Motivation, and Learning. Online Journal of Communication and Media Technologies, 1(4), 17-33

El-Fatihi, M. (2006). The Role of Nonverbal Communication in Beginner's EFL Classrooms. Retrieved Nov 14, 2014, from http://www.ehc.ed.gov

Ellis,K.(2000). Perceived Teacher Confirmation: the Development and Validation of an Instrument and Two Studies of the Relationship to Cognitive and Affective learning. Human Communication Research, 26(2), 264-291

Erbay, F., Omeroglu, E., \& Cagdas, A. (2012). Development and Validity - Reliability Study of a Teacher - Child Communication Scale. Educational Sciences: Theory \& Practice, 3165 (3172), 3165 - 3172

Faylor, N., Beebe, S. Houser, M., \& Mottet, T. (2008). Perceived Differences in Instructional Communication Behaviors between Effective and Ineffective Corporate Trainers. A Publication of the Pacific and Asian Communication Association, Human Communication, 11(1), 145 - 156 


\section{الجمعية المصرية للقراءة والمعرفة عضو الجمعية الدولية للمعرفة ILA}

Freeman, N.P. (2011). Credibility and the Professor: The Juxtaposition of Student Perceptions and Instructor Beliefs. (Master's Thesis, Department of Communication, University of Central Missouri). Retrieved from http://www. centralspace.ucmo.edu

Frymier, A.B., \& Wanzer, M.B. (2006). Teacher and Student Affinity Seeking in the Classroom. In Mottet, T.P. Richmond V.P. \& McCroskey, J.C. Handbook of Instructional Communication. Rhetorical and Relational Perspectives. (195 - 212). Boston: Allyn \& Bacon.

Ginsberg, S.M. (2004). The Role of Classroom Communication in Collage Faculty Transparency. (Doctoral Dissertation, Eastern Michigan University). Available from ProQuest Dissertation and Theses Database (UMI NO. 3158530).

Glomo - Narzoles, D.T. (2013). Classroom Communication Climate and Communicative Linguistic Competence of EFL Learners. Theory and Practice in Language Studies, 3(3), 404 - 410

Goodboy,A.K.(2007). The Effect of Teacher Confirmation on Student Communication and Learning Outcomes. (Doctoral Dissertation, Eberly College of Arts and Sciences, West Virginia University). Retrieved from http://www.tandfonline.com

Goodboy,A.K. \& Myers,S.A.(2008). The Effect of Teacher Confirmation on Student Communication and Learning Outcomes. Communication Education, 57(2), 153-179

Goolamhossen, F. (2013). A study on the Perception of Pre-service School Teachers on the Importance of Effective Communication Skills for Teaching. $2^{\text {nd }}$ International Conference on Communication, Media, Technology and Design (02-04 May, 2013). Mauritius Institute of Education. Retrieved March 15, 2014, from http://www. cmdconf.net

Hughes, G.K. (2014). The Effect of Mediated Immediacy upon State Motivation and Cognitive Learning in an on Line Lesson. (Doctoral Dissertation, Collage of Communication and Information, University of Kentucky). Retrieved from http://www.uknowledge.uky.edu

Hsu, L., Watson, T., Lin, Ch., \&Ho, T. (2007). Explorations in Teachers' Nonverbal Immediacy Behaviors and Students' Willingness to Talk in English. English Teaching \&Learning, 31(3), 1-27 
Hsu, L. (2010). The Impact of Perceived Teachers' Nonverbal Immediacy on Students' Motivation for Learning English. Asian EFL Journal, 12 (4), 1-17

Ihmeideh, F., Al - Omari, A., \& Al - Dababneh, K. (2010). Attitudes Toward Communication Skills among Students' - Teachers' in Jordanian Public Universities, Australian Journal of Teacher Education, 35(4), 1 - 12

Ismail, N. (2009). The Effects of Classroom Communication on Students' Academic Performance at the International Islamic University Malaysia. UNITAR E-Journal, 5(1), 37 - 49

Jacennik, B. (2005). Measuring Children's Assertiveness from Conversational Samples. Psychology of Language and Communication, 9(2), 43 $-52$

Johnson, A.D., \& McCroskey, J.C. (2004). Machiavellianism, Biological Sex, and Communication Orientations. Human Communication, 2(13), 57 - 67

Krathwohl, D.R. (2002). A Revision of Bloom's Taxonomy: An Overview. Theory into Practice, 41(4), 212-218

MacGregor, I.M. (2001). Toward Mutual Responsibility in Classroom Communication: Exploring College Student Classroom Communication. (Doctoral Dissertation, College of the Liberal Arts, the Graduate School, the Pennsylvania State University). Available from ProQuest Dissertation and Theses Database. (UMI NO. 3036076)

Mathis, R.S. (2006). A Review of Literature Examining the Application of Instructional Communication to the Training and Development Profession. Texas A\&M University, pp. 288- 294, Retrieved Nov14, 2014, from http://www.files-eric.ed.gov

Maurine, K., Indoshi, F., Okwach, T., \& Osodo, J. (2012). The Nature of Communication Process in Kiswahili Language Classrooms. International Journal of Educational Research and Technology, 3(2), 141 - 145, Retrieved Jan 19, 2018, from http:// www.soeagra.com

McCroskey, J.C., \& Richmond, V.P. (1992). An Instructional Communication Program for in - Service Teachers. Communication Education, $41,215-220$

McCroskey, J.C., Heisel, A.D, \&Richmond, V.P. (2001). Eysenck's Big Three and Communication Traits: Three Correlation Studies. Communication Monographs, (68)3, 360 - 366 


\section{الجمعية المصرية للقر اعة والمعرفة عضو الجمعية الدولية للمعرفة ILA}

McCroskey, J.C., Valencic, K.M., \& Richmond, V.P (2004). Toward a General Model of Instruction Communication. Communication Quarterly, 52(3), $197-210$

McCroskey, J.C., Richmond, V.P., \&McCroskey, L.L. (2006). An Introduction to Communication in the classroom: the Role of Communication in Teaching and Training. Boston, MA: Allyn \& Bacon

Mottet,T., Garza,R., Beebe,S., Houser,M., Jurrells ,S., \& Furler, L. (2008). Instructional Communication Predictors of Ninth-Grade Students' Affective Learning in Math and Science. Communication Education, 57(3), 333 $-355$

Mottet, T.P., Richmond, V.P., \& McCroskey, J.C. (2006). The Hand book of Instructional Communication: Rhetorical and Relational Perspectives. Boston, MA: Allyn \& Bacon

Myers, S.A., \& Martin, M.M. (2006). Understanding the Source: Teacher Credibility and Aggressive Communication Traits. In Mottet, T.P. Richmond, V.P., and McCroskey, J.C., Hand Book of Instructional Communication: Rhetorical and Relational Perspectives (pp. 67 - 88) Boston: Allyn \& Bacon

Myers, S.A. (2010). Instructional Communication: The Emergence of a Field Retrieved Mar 5, 2014, from http://www.uk.sagepub.com

Ozmen, K.S. (2011). Perception of Nonverbal Immediacy and Effective Teaching among Student Teachers: Study across Cultural Extremes. International on Line Journal of Educational Sciences, 3(3), 865 - 881

Pei, B. (2013). Study on the Instructional Communication Process to Multimedia Assisted Collage English Teaching. Journal of Chemical and Pharmaceutical Research, 5(12), 668 - 674

Rajab,A. \& Che Abas,A.(2010).Self-Concept and Communication Skills: a Focus among UTM Final Year TESL Students. Retrieved Feb 25, 2014, from http://www.eprints.utm.my

Richmond, V. (1990). Communication in the Classroom: Power and Motivation. Communication Education, 39, 181-195

Richmond, V.P., Lane, D.R., \& McCroskey, J.C. (2006). Teacher Immediacy and the Teacher - Student Relationship. In Mottet, T.P., Richmond V.P., \& McCroskey, J.C., Handbook of Instructional Communication: Rhetorical and Relational Perspectives (pp. 167 - 194). Boston: Allyn \& Bacon. 
Roach, D.K., Richmond, V.P., \& Mottet, T.P. (2006). Teachers' Influence Messages. In Mottet, T.P., Richmond, V.P., \& McCroskey, J.C., Handbook of Instructional Communication: Rhetorical and Relational Perspectives (pp. 117 - 140). Boston: Allyn \& Bacon.

Runcan, P., Goian, C., \& Tire, L. (2012). The Socio - Communicational Style and the Need for Supervision of Professionals from the Social Services. Review of Research and Social Intervention, 37, 180 - 195

Russ, T.L., Simonds, C.J., \& Hunt, S.K. (2002). Coming out in the Classroom: An Occupational Hazard, the Influence of Sexual Orientation on Teacher Credibility and Perceived Student Learning. Communication Education, $51(3), 311-324$

Saechou, T. (2005). Verbal and Nonverbal Immediacy: Sex Differences and International Teaching Assistants. (Doctoral Dissertation, Agricultural and Mechanical College, Louisiana State University). Retrieved Dec 3, 2014, from http://www. digitalcommons.lsu.edu

Shu-Fang, N., \& Adust, R. (2008). Examining Teacher Verbal Immediacy and Sense of Classroom Community in on Line Classes. International JL. On Elearning, 7(3), $477-498$

Sidelinger, R.J. \& McCroskey, J.C. (1997). Communication Correlates of Teacher Clarity in the College Classroom. Communication Research Reports, 14(1), 1-10

Simmons, C.M. (2011). Perceived Confirmation and Disconfirmation in Community College Online Distance- Learning Courses. (Master's Thesis, Faculty in Communication and Leadership Studies, Gonzaga University). Available from ProQuest Dissertation and Theses Database, (UMI NO. 1493620)

Singhal, A. \& Nagao, M. (1993). Assertiveness as Communication Competence: A Comparison of the Communication Style of American and Japanese Students. Asian Journal of Communication, 3(1), 1 - 18

Tabasco, D. (2007). Investigation of Relationships among Teachers' Immediacy and Creativity, and Students' Perceived Cognitive Learning. (Doctoral Dissertation, Drexel University). Retrieved Jan 25, 2015, from http://www. idea.library.drexel.edu 
Teven, J.J, \& McCroskey, J.C. (1996). The Relationship of Perceived Teacher Caring with Student Learning and Teacher Evaluation. The Annual Meeting of the Speech Communication Association (2nd San Diego, CA), pp. $23-26$

Teven, J. (2012). Translating Research into Instructional Practice: Instructor Credibility. Retrieved Nov 14, 2014, from http://www.natcom.org

Thaahaveettil, B. (2012). Factors of Effective Classroom Communication. Retrieved Jan 27, 2015, from http://www.wikieducator.org

Valencic, K.M, McCroskey, J.C., \& Richmond, V.P. (2005). The Relationship between Teachers' Temperament and Students' Perceptions of Teacher Communication Behavior. Retrieved Jan 9, 2014, from http://www.jamescmccroskey.com

Velez, J. \& Cano, J. (2008). The Relationship between Teacher Immediacy and Student Motivation. Journal of Agricultural Education, 49(3), 76 - 86

Waldeck, J.H. (2007). Answering the Question: Student Perceptions of Personalized Education and Constructs' Relationship to Learning Outcomes, Communication Education, 56(4), 409-432

Winters, F.L. (2014). Faculty Communication in the Undergraduate College Classroom: A Student Perspective. (Doctoral Dissertation, Faculty of Drexel University). Available from ProQuest Dissertation and Theses Database, (UMI NO. 3638326)

Woods, C. (2007). Researching and Developing Interdisciplinary Teaching: Towards a Conceptual Framework for Classroom Communication. Higher Education, 54(6), 853 - 866, Retrieved Nov 17, 2014, from http://www.jstor.org

Wrench, J.S. \& McCroskey, J.C. (2008). Organizational Coaching as Instructional Communication. Human Communication, 11(3), 273 - 286

Wrench, J.S., Richmond, V.P. \& Gorhann, J. (2009). Communication, Affect and Learning in the Classroom. 3rd Edition, California, USA: Tapestry Press. (ISBN: 1-56888-548-2)

Zhang, Q., \& Sapp, D. (2009). The Effect of Perceived Teacher Burnout on Credibility. Communication Research Reports, 26(1), 87 - 90 